\section{Effects of Maleic Hydrazide Treatment on the Size and Number of Cells and Sugar Accumulation in the Fruit of Melons (Cucumis melo L.)}

\author{
Yasutaka Kano \\ Ishikawa Prefectural University, Bioproduction Science, Suematsu 1-308, \\ Nonoichi, Ishikawa, 921-8836, Japan
}

Additional index words. cell size, Cucumis melo L., maleic hydrazide, number of cells, sugar accumulation

\begin{abstract}
The relationships between the size and the number of cells and sugar accumulation in melon fruit have been examined. Maleic hydrazide (MH) was used to investigate the relationships. Although cell size was markedly larger in MH-treated fruit than in untreated fruit in the early stages of fruit development, the number of cells in MH-treated fruit was less than in untreated fruit in latter fruit development. Sucrose, glucose, and fructose content were higher in MH-treated fruit than in untreated fruit. It is therefore suggested that sucrose accumulation in fruit subjected to MH treatment is accelerated as a result of early cell enlargement and that sucrose content increases further as a result of the decrease in the number of cells in the fruit during late development.
\end{abstract}

Sucrose is the most important factor determining the sweetness of melon fruit. The rate of sucrose accumulation in melon fruit increases during the latter half of the fruit development as the result of cell enlargement (Kano, 2002). In addition, sucrose accumulation has been demonstrated to occur in response to cellular enlargement if cell size is increased by auxin treatment during early fruit development (Kano, 2002) as well as in response to heating fruits (Kano, 2006). Conversely, sucrose accumulation in melon fruit can be suppressed by mechanical restriction resulting from relative decreases in the number of large cells associated with such treatment (Kano, 2004a) or by treatment with plant growth inhibitors (Kano, 2004b). Sucrose accumulation is suppressed in Japanese pears as a result of an increase in the number of small cells that result from 2-chloro-4-pyridyl-N-phenylurea treatment (Kano, 2003). Thus, it is considered that increased sucrose accumulation is associated with a higher number of large cells relative to small cells in the fruit. Most of the imported sugars accumulate in the vacuole of sinktissue storage cells (Leigh et al., 1979; Yamaki and Ino, 1992). Cell size during the latter stage of fruit development is mostly equal to that of the vacuole because vacuoles in peaches force the cytoplasm to the outside of the mesocarp cells in the middle stages of fruit development (Ishida et al., 1973). Taken together, these findings suggest that the

Received for publication 5 Dec. 2006. Accepted for publication 26 Feb. 2007.

I thank Ms. S. Tasaka and Ms. M. Maeguchi for their technical assistance. E-mail gansho@ ishikawa-pu.ac.jp. occurrence of lots of large cells is associated with increased sucrose content. The treatment of seeds with maleic hydrazine $(\mathrm{MH})$ was found to increase cell size and vacuolation in wheat seedlings (Mendhulkar, 2000), shown to increase cell length in algae (Gupta and Kumar, 1970). Furthermore, the inhibition of sprouting in onion has been demonstrated by $\mathrm{MH}$ treatment (Benkeblia, 2004; Benkeblia et al., 2002; El-Otmani et al., 2003) as a result of its effects on inhibiting cell division (Marcano, et al., 2004; Zilkah, et al.,1981), Thus, MH treatment has the effect of both accelerating cell enlargement as well as inhibiting cell division. Consequently, I hypothesized that sucrose content increases in melon fruit with early cell enlargement and with a cessation in cell division after an inflexion point.

I therefore treated melon fruit with $\mathrm{MH}$ to clarify the relationship between the size and the number of cells and sugar accumulation in the fruit.

\section{Materials and Methods}

Plant materials. Earl's Knight Natsukei No.2 (Cucumis melo L.) melon seeds were planted in a seedbed on 20 Mar. 2004 with nursery plants spaced at $40-\mathrm{cm}$ intervals in a plastic film greenhouse on $20 \mathrm{Apr}$. 2004. The flowers that opened on $\approx 14$ June were used in this experiment. Only one fruit was borne on about the 12th node of each plant and the main stems were pinched at the 20th node. Three fruits were used in each treatment. The fruits on the 30th day after anthesis (DAA), considered to be the time when sucrose accumulation is initiated, were thoroughly sprayed with an $\mathrm{MH}$ solution at $2000 \mathrm{mg} \cdot \mathrm{L}^{-1}$. and low concentrations of $\mathrm{MH}$ have been
The three fruits that were collected and weighed at 40 and $50 \mathrm{DAA}$ for the control and $\mathrm{MH}$ treatments, respectively, were used for cell size and sugar analyses.

Measurements of cell number and size in the fruit. Two $\approx 10-\mathrm{mm}$ thick disks were cut from each of the three fruit from the control and $\mathrm{MH}$-treated plants; one disk was excised from the fruit at the maximum transverse diameter toward the calyx end for cell analysis, whereas another was excised from the maximum transverse diameter toward the peduncle end for sugar analysis. Using a sharp table knife, a sample measuring $\approx 10 \mathrm{~mm} \times$ $10 \mathrm{~mm}$ was removed from the disk with $5 \mathrm{~mm}$ straddling the maximum diameter line across each disk (Fig. 1). Rectangular parallelepipeds (hereafter RP), each measuring $7 \mathrm{~mm}$, were serially sampled across the diameter of the disk using the same sharp table knife. Except for the RP containing seeds and the RPs at both ends containing the epidermis, all of the RPs along the 7-mm-long strips through the diameter of the fruit body were 8 and 9 and 12 and 12 at 40 and 50 DAA, respectively. All of the RPs obtained from fruit from each treatment were dehydrated by treatment using a series of alcohol concentrations $(70 \%, 80 \%, 90 \%$, and $100 \%)$ before being embedded in paraffin. Seven $10-\mu \mathrm{m}-$ thick sections were prepared from these paraffin blocks, and the clearest section from each RP treatment was examined under a microscope. As shown in Figure 2, the maximum diameters of individual cells along the maximum transverse diameters of the RPs were measured. Cell size was calculated by dividing the total cell diameter measured in each RP from the three fruits or all RPs of three fruits by the number of cells of each RP of three fruits or the number of cells of all RPs of three fruits.

Sugar analysis. The RPs from the disk taken from the maximum transverse diameter toward the peduncle end were used for sugar analysis. With exception of those RPs containing the seeds and both epidermal layers, all of the RPs were wrapped in cheesecloth and squeezed using pincers to extract the juice. The juice was diluted 10 times with distilled water before being centrifuged at $8000 \times g$ for $15 \mathrm{~min}$ and filtered through a $0.45-\mu \mathrm{m}$ filter. Then, $20 \mu \mathrm{L}$ of filtrate was analyzed by high-performance liquid chromatography (LXC-10ADvp; Shimadzu, Kyoto, Japan) fitted with a refractive index detector (RID-10A; Shimadzu) equipped with Shim-pack SCR-101C (Shimadzu) at $0.8 \mathrm{~mL} \cdot \mathrm{min}^{-1}$ at $80{ }^{\circ} \mathrm{C}$. Standard solutions of sucrose, glucose, and fructose at 20,000 $\mathrm{mg} \cdot \mathrm{L}^{-1}$ were injected into the high-performance liquid chromatograph before injection of the filtrates. Mean sucrose, glucose, and fructose content in each RP was calculated by dividing the total sucrose, glucose, and fructose content of each RP from three fruits by three. Mean sucrose, glucose, and fructose content in whole fruits was then estimated by dividing the total sucrose, glucose, and fructose content of all RPs from three fruits by the total number of PRs from the three fruit. 


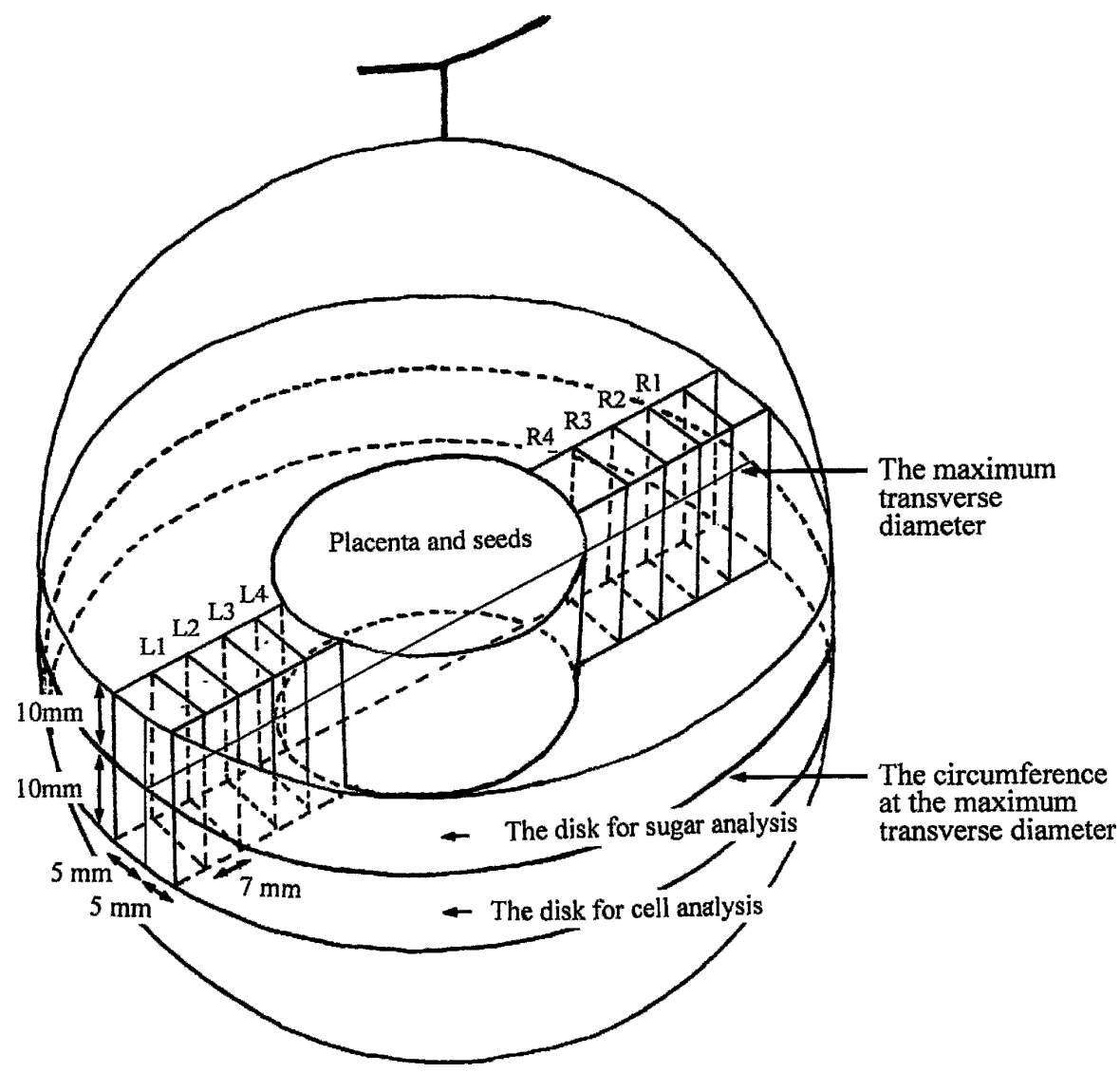

Fig. 1. An illustration of the collection of rectangular parallelepiped (RP) parts for the determination of the size and number of cells and sugar content in melon fruits. This is an example for the untreated fruit on $40 \mathrm{~d}$ after anthesis.

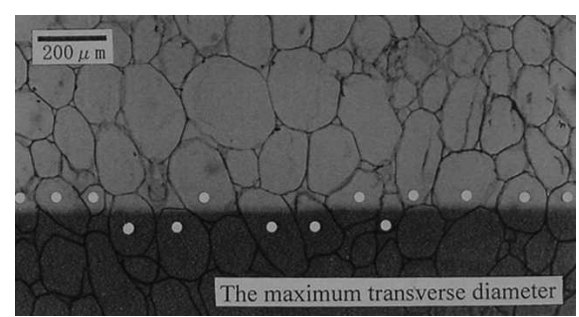

Fig. 2. An illustration of the measurement of the size and the number of cells of melon fruits 40 $\mathrm{d}$ after anthesis. White dots indicate the actual cells measured.

\section{Results}

The weights of $\mathrm{MH}$-treated fruit at 40 and 50 DAA were not observed to differ from those of the untreated fruit (Fig. 3).

The number of RPs with mean cell size larger than $250 \mu \mathrm{m}$ at $40 \mathrm{DAA}$ numbered three in the $\mathrm{MH}$-treated fruit batch compared with one in the untreated fruit, and the number of RPs with a mean cell size exceeding $250 \mu \mathrm{m}$ at $50 \mathrm{DAA}$ was six in MH-treated fruit and eight in the untreated fruit (Table 1). Mean cell size for all RPs from MH-treated fruit at 40 DAA was $247 \mu \mathrm{m}$, whereas the fruit at 50 DAA did not differ between the two treatments. Although the number of RPs with more than 25 cells was eight in both treatments at $40 \mathrm{DAA}$, at $50 \mathrm{DAA}$, the
However, it does not always follow that the sucrose content in RPs of MH-treated fruit with larger cells at $40 \mathrm{DAA}$ is greater than that found in RPs of untreated fruit with smaller cells at 40 DAA (Tables 1 and 3). In fact, the sucrose content of RPs from MHtreated fruit with a smaller number of cells at 50 DAA is always higher than that found in RPs with a large number of cells in the untreated fruit (Tables 2 and 3 ).

\section{Discussion}

Cell size at 40 DAA was markedly greater in $\mathrm{MH}$-treated fruit compared with untreated fruit. The MH treatment of seeds was found to increase cell size and vacuolation in wheat seedlings (Mendhulkar, 2000). Similarly, treatment with low concentrations of $\mathrm{MH}$ increases cell length in algae (Gupta and Kumar, 1970). Taken together, these results lend support to the hypothesis that the increase in cell size in MH-treated fruit at $40 \mathrm{DAA}$ is attributable to the stimulation of cell enlargement by $\mathrm{MH}$ itself. Sucrose content was greater in $\mathrm{MH}-$ treated fruit at 40 DAA than in untreated fruit. Generally, the small vacuoles of meristematic cells increase in size and gradually coalesce as the cells enlarge and age (Esau, 1964). Most of the imported sugars accumulate in the vacuole of sink-tissue storage cells (Leigh et al., 1979; Yamaki and Ino, 1992). The mean cell volume of strawberry fruit increases slowly during active cell division, but rises rapidly and linearly for $10 \mathrm{~d}$ after cell division stops (Guiwen and Breen, 1992) with sucrose content in the vacuoles of strawberry fruit increasing from 25 to 35 DAA (Ofosu-Anim and Yamaki, 1994). Sucrose accumulates rapidly in the larger cells of melon fruit (Kano, 2002) because cell enlargement during early melon development results in dramatically increased sucrose content as a result of the increased duration of sucrose accumulation before harvesting (Kano, 2005). The treatment of various crops with $\mathrm{MH}$ has also been demonstrated to increase leaf carbohydrate content (Currier et al., 1951; Derridj et al., 1986), especially Gossypium herbaceum (McIlrath, 1950), Zea mays (Naylor, 1951) and Nicotiana tabacum (Seltmann and Nichols, 1984). Given these results, it is reasonable to assume that the sucrose accumulation in the cells of melon fruits treated with MH increases as a result of the early enlargement of vacuoles by rapid cell enlargement.

A fewer number of cells were found in $\mathrm{MH}$-treated fruit at 50 DAA compared with the untreated fruit. After reaching the inflection point, before which fruit growth is primarily the result of cell division, any increase in melon size is the result of cell enlargement only. In the fruits of Cucurbits, this usually occurs when the fruit diameter is $\approx 20 \mathrm{~mm}$ (Masuda, 1970; Sinnott, 1939). Cell division in the tissues near the exocarp in the fruit of Lagenaria vulgaris continues until the middle stages of fruit growth (Sinnott, 1939) with cellular multiplication continuing until harvest in the fruit of the avocado (Schroeder, 1953). In this study, the total 
Table 1. Effects of maleic hydrazide $(\mathrm{MH})$ treatment on cell size $(\mu \mathrm{m})$ in each rectangular parellepiped (RP) and in all the RPs.

\begin{tabular}{|c|c|c|c|c|c|c|c|c|c|}
\hline & & $\mathrm{RP}$ & Cell size & No. & & & $\mathrm{RP}$ & Cell size & No. \\
\hline \multirow[t]{11}{*}{$\overline{40 \text { DAA }}$} & Control & L1 & $202 \pm 78$ & 60 & & MH-treated & L1 & $227 \pm 101$ & 80 \\
\hline & & L2 & $226 \pm 79$ & 84 & & & L2 & $261 \pm 75$ & 82 \\
\hline & & L3 & $232 \pm 93$ & 54 & & & L3 & $270 \pm 85$ & 69 \\
\hline & & L4 & $224 \pm 70$ & 81 & & & L4 & $242 \pm 76$ & 84 \\
\hline & & R4 & $195 \pm 60$ & 79 & & & L5 & $199 \pm 74$ & 5 \\
\hline & & R3 & $221 \pm 72$ & 81 & & & $\mathrm{R} 4$ & $249 \pm 74$ & 78 \\
\hline & & $\mathrm{R} 2$ & $250 \pm 72$ & 75 & & & R3 & $238 \pm 85$ & 85 \\
\hline & & R1 & $204 \pm 100$ & 83 & & & $\mathrm{R} 2$ & $258 \pm 65$ & 75 \\
\hline & & & & & & & $\mathrm{R} 1$ & $223 \pm 93$ & 93 \\
\hline & Mean & & $221 \pm 80$ & 597 & & & & $247 \pm 84$ & 701 \\
\hline & Statistical significance & & & & $* *$ & & & & \\
\hline \multirow[t]{12}{*}{$50 \mathrm{DAA}$} & Control & L1 & $261 \pm 97$ & 87 & & MH-treated & L1 & $239 \pm 70$ & 68 \\
\hline & & L2 & $260 \pm 78$ & 56 & & & L2 & $286 \pm 75$ & 70 \\
\hline & & L3 & $266 \pm 74$ & 85 & & & L3 & $264 \pm 78$ & 72 \\
\hline & & L4 & $252 \pm 67$ & 75 & & & L4 & $264 \pm 83$ & 1 \\
\hline & & L5 & $231 \pm 69$ & 91 & & & L5 & $223 \pm 61$ & 4 \\
\hline & & R5 & $250 \pm 63$ & 62 & & & R5 & $234 \pm 60$ & 71 \\
\hline & & $\mathrm{R} 4$ & $292 \pm 69$ & 91 & & & $\mathrm{R} 4$ & $239 \pm 69$ & 64 \\
\hline & & R3 & $281 \pm 70$ & 78 & & & R3 & $265 \pm 73$ & 70 \\
\hline & & $\mathrm{R} 2$ & $284 \pm 100$ & 82 & & & $\mathrm{R} 2$ & $271 \pm 88$ & 7 \\
\hline & & R1 & $240 \pm 87$ & 95 & & & R1 & $271 \pm 78$ & 7 \\
\hline & Mean & & $261 \pm 81$ & 802 & & & & $257 \pm 76$ & 676 \\
\hline & significance & & & & NS & & & & \\
\hline
\end{tabular}

Data are means \pm SD.

No.; actual number of cells employed for mean cell size in each RP and in all the RPs.

${ }^{\mathrm{Ns}, * *}$ Nonsignificant and significant at $P<0.01$, respectively, by $t$ test.

Refer to Figure 1 for RPs in the table.

DAA: days after anthesis.

Table 2. Effects of maleic hydrazide (MH) treatment on mean number of cells in each rectangular parelleepiped (RP) and mean number of cells in all the RPs and total number of cells in the fruit.

\begin{tabular}{|c|c|c|c|c|c|c|c|}
\hline & & $\mathrm{RP}$ & $\begin{array}{l}\text { No. of } \\
\text { cells }\end{array}$ & & & $\mathrm{RP}$ & $\begin{array}{l}\text { No. of } \\
\text { cells }\end{array}$ \\
\hline \multirow[t]{12}{*}{$\overline{40 \mathrm{DAA}}$} & Control & L1 & $30 \pm 10$ & & MH-treated & L1 & $27 \pm 2$ \\
\hline & & L2 & $28 \pm 3$ & & & L2 & $27 \pm 4$ \\
\hline & & L3 & $26 \pm 4$ & & & L3 & $23 \pm 2$ \\
\hline & & L4 & $27 \pm 0$ & & & L4 & $28 \pm 3$ \\
\hline & & R4 & $26 \pm 4$ & & & L5 & $28 \pm 6$ \\
\hline & & R3 & $27 \pm 3$ & & & R4 & $26 \pm 4$ \\
\hline & & R2 & $25 \pm 3$ & & & R3 & $28 \pm 8$ \\
\hline & & R1 & $28 \pm 2$ & & & R2 & $25 \pm 2$ \\
\hline & & & & & & R1 & $31 \pm 3$ \\
\hline & Mean no. in RP & & $27 \pm 3$ & & & & $27 \pm 4$ \\
\hline & Statistical significance & & & NS & & & \\
\hline & Total no. in the fruit & & $216 \pm 16$ & & & & $242 \pm 3$ \\
\hline \multirow{14}{*}{$50 \mathrm{DAA}$} & Control & L1 & $29 \pm 5$ & & MH-treated & L1 & $23 \pm 1$ \\
\hline & & L2 & $28 \pm 3$ & & & $\mathrm{~L} 2$ & $23 \pm 3$ \\
\hline & & L3 & $28 \pm 2$ & & & L3 & $24 \pm 4$ \\
\hline & & L4 & $25 \pm 2$ & & & L4 & $25 \pm 5$ \\
\hline & & L5 & $30 \pm 8$ & & & L5 & $22 \pm 1$ \\
\hline & & R5 & $31 \pm 8$ & & & R5 & $24 \pm 5$ \\
\hline & & R4 & $26 \pm 2$ & & & R4 & $21 \pm 1$ \\
\hline & & R3 & $26 \pm 7$ & & & R3 & $23 \pm 2$ \\
\hline & & $\mathrm{R} 2$ & $27 \pm 6$ & & & $\mathrm{R} 2$ & $24 \pm 4$ \\
\hline & & R1 & $32 \pm 5$ & & & R1 & $23 \pm 3$ \\
\hline & Mean no. in RP & & $28 \pm 5$ & & & & $23 \pm 3$ \\
\hline & Statistical significance & & & $* *$ & & & \\
\hline & Total no. in the fruit & & $282 \pm 19$ & & & & $232 \pm 12$ \\
\hline & Statistical significance & & & * & & & \\
\hline
\end{tabular}

Data are means $\pm \mathrm{SD}$.

Number of values in each RP for mean was three and mean number of values in all the RPs was $24(3 \times 8)$, $27(3 \times 9)$, and $30(3 \times 10)$ in the control 40 DAA, MH-treated 40 DAA, control 50 DAA and MH-treated 50 DAA, respectively.

Ns,****Nonsignificant or significant at $P<0.05,0.01$, respectively by $t$ test.

Refer to Figure 1 for RPs in the table.

DAA: days after anthesis.

number of cells in the untreated fruit increased from 217 to 282 at 40 to 50 DAA, respectively (refer to Table 2). Consequently, slower rates of cell division, not as active as before the inflection point, are likely to continue during has elapsed. Moreover, sucrose content was considerably higher in MH-treated fruit than in the untreated fruit 50 DAA. No cell division was observed during the latter stages of fruit development as a result of $\mathrm{MH}$ treatment, resulting in the production of fewer large cells and thus, smaller sucrose sink for the whole fruit. Consequently, the constant and active sucrose accumulation in large cells, which are fewer in number in MH-treated fruit, has the effect of further increasing sucrose content.

However, a clear relationship between cell size and sucrose content was not observed in RPs from untreated fruit and MH-treated fruit at 40 and 50 DAA. Although numerous vascular bundles develop in the mesocarp and endocarp of melon fruit, they change in number and diameter as a result of differential growth in the fruit (Kanahama and Saito, 1987). This is likely to be the reason for the apparent absence of any relationship between cell size and sucrose content of the RPs examined.

The following conclusion can be drawn from the results observed in $\mathrm{MH}$-treated fruits: sucrose accumulation is promoted as a result of early cell enlargement associated with $\mathrm{MH}$ treatment and the concomitant decrease in the number of cells in the fruit during late development, which results in a further increase in sucrose content.

\section{Literature Cited}

Benkeblia, N. 2004. Effect of maleic hydrazine on respiratory parameters of stored onion bulbs (Allium cepa L.). Bra. J. Plant Physiol. 16:47-52.

Benkeblia, N., P. Varoquaux, N. Shiomi, and H. Sakai. 2002. Storage technology of onion bulbs cv. Rouge Amposta: Effects of irradiation, maleic hydrazide and carbamate isopropyl N-phenyl (CIP) on respiration rate and carbohydrates. Inter. J. Food Sci. Tech. $37: 169-175$

Currier, H.B., B.E. Day, and A.S. Crafts. 1951 Some effects of maleic hydrazide on plants. Bot. Gaz. 112:272-280.

Derridj, S., V. Fiala, and E. Jolivet. 1986. Increase of European corn borer (Ostrinia nubilalis) oviposition induced by a treatment of maize plants with maleic hydrazide: Role of leaf carbohydrate content. Entomol. Exp. Appl. 41:305-310.

El-Otmani, M., A. Ndiave, A. Ait-Oubahou, and A. Kaanane. 2003. Effects of preharvest foliar application of maleic hydrazide and storage conditions on onion quality postharvest. Acta Hort. 628:615-622.

Esau, K. 1964. Vacuoles, p. 23-25. In: Plant anatomy. John Wiley \& Sons, Inc., New York, London, Sydney.

Guiwen, W.C. and P.J. Breen. 1992. Cell count and size in relation to fruit size among strawberry cultivars. J. Amer. Soc. Hort. Soc. 117:946-950.

Gupta, R.S. and H.D. Kumar. 1970. The effect of maleic hydrazide on growth and mutation of a blue-green alga. Arch. Microbiol. 70:330-339.

Ishida, M., A. Inaba, and Y. Sobajima. 1973 Physiological studies on the growth and development of peach fruits. I. Anatomical changes during the development of peach fruits. Sci. Rep. Kyoto Pref. Univ. Agr. No. 25:1-8.

Kanahama, K. and S. Saito. 1987. Vascular system and carpel arrangement in the fruits of melon, cucumber and Luffa acutangula Roxb. J. Jpn. Soc. Hort. Sci. 55:476-483. 
Table 3. Effects of maleic hydrazide $(\mathrm{MH})$ treatment on sugar content $\left(\mathrm{g} \cdot \mathrm{L}^{-1}\right)$ in each rectangular parellepiped (RP) and mean content in all the RPs.

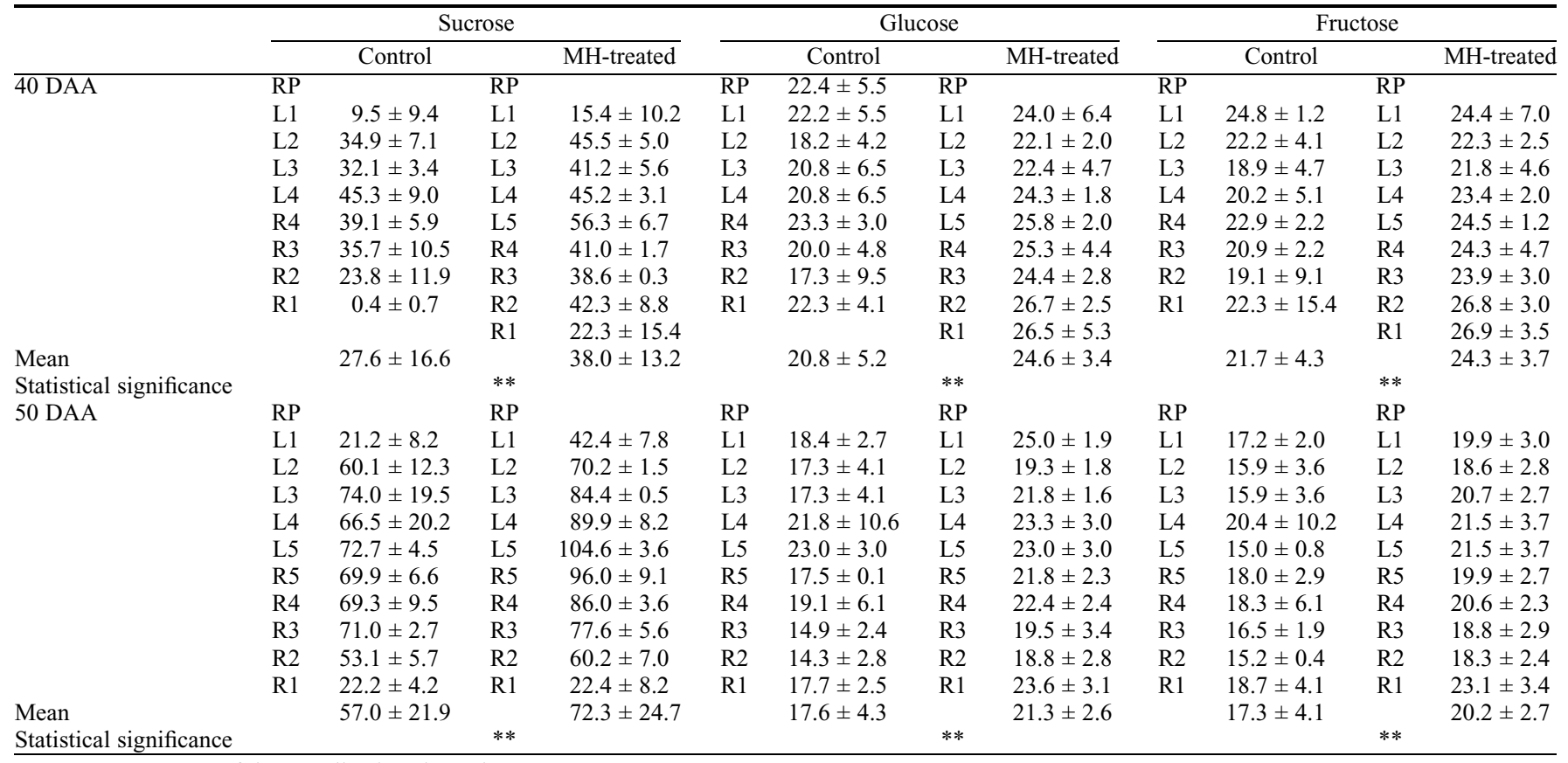

Data are means \pm SD of three replications in each RP.

The values of mean in the table are means \pm SD of $24(3 \times 8), 27(3 \times 9)$, and $30(3 \times 10)$ replications in the control fruit 40 DAA, MH-treated fruit 40 DAA, the control fruit $50 \mathrm{DAA}$ and $\mathrm{MH}$-treated $50 \mathrm{DAA}$, respectively.

*** Significant at $P<0.01$ by test.

Refer to Figure 1 for RPs in the table.

DAA $=$ days after anthesis.

Kano, Y. 2002. Relationship between sucrose accumulation and cell size in 4-CPA-treated melon fruits (Cucumis melo L.). J. Hort. Sci. Biotechnol. 77:546-550.

Kano, Y. 2003. Effect of GA and CPPU treatments on cell size and type of sugars accumulated in Japanese pear fruit. J. Hort. Sci. Biotechnol. 78:331-334.

Kano, Y. 2004a. Effect of mechanical restriction of fruit enlargement on cell size and sucrose accumulation in melon fruits (Cucumis melo L.). Acta Hort. 662:369-372.

Kano, Y. 2004b. Effect of SADH treatment on cell size and kind of sugars accumulated in melon fruits. J. Hort. Sci. Biotech. 79:14-17.

Kano, Y. 2005. Comparison of the effects of 4-CPA and CPPU treatment on melon cell size and sugar accumulation. Environ. Control Biol. 43:147-154.

Kano, Y. 2006. Effect of heating fruit on cell size and sugar accumulation in melon fruit ( $\mathrm{Cucu}$ mis melo L.). HortScience 41:1-4.
Leigh, R.A., T. Apree, W.A. Fuler, and J. Bonfield. 1979. The location of acid invertase and sucrose in vacuoles isolated from storage roots of red beet (Beta vulgaris L.). Biochem. J. 178:53-57.

Marcano, L., I. Carruyo, A. Del. Campo, and X. Montiel. 2004. Cytotoxicity and mode of action of maleic hydrazide in root tips of Allium cepa L. Environ. Res. Acad. Press. Orlando, FL, USA. 94:221-226.

Masuda, T. 1970. 6. Effects of some environments on cell division in the fruit flesh, p. 69-78. Studies on the development of melon fruits. Kyoto University, Kyoto, Japan, PhD Diss

McIlrath, W.J. 1950. Response of the cotton plant to maleic hydrazide. Amer. J. Bot. 37:816-819.

Mendhulkar, V.D. 2000. Effect of maleic hydrazide on somatic cells and nuclear size in Triticum aestivum Linn. Advances in Plant Sciences. Acad., Plant Sci. Muzaffarnager, India. 13:567-572.

Naylor, A.W. 1951. Accumulation of sucrose in maize following treatment with maleic hydrazide. Arch. Biochem. Biophys. 33:340-342.
Ofosu-Anim, J. and S. Yamaki. 1994. Sugar content, compartmentation, and efflux in strawberry tissue. J. Amer. Soc. Hort. Sci. 119:1024 1028.

Schroeder, C.A. 1953. Growth and development of the Fuerte avocado fruit. J. Amer. Soc. Hort. Sci. 61:103-109.

Seltmann, H. and B.C. Nichols. 1984. Agronomic, physical and visual characteristics of hand suckered on maleic hydrazide treated flue-cured and burley tobaccos. Agron. J. 76:375-378.

Sinnott, E.W. 1939. A developmental analysis of the relation between cell size and fruit size in Cucurbits. Amer. J. Bot. 26:179-189.

Yamaki, S. and M. Ino. 1992. Alteration of cellular compartmentation and membrane permeability to sugars in immature and mature apple fruit. J. Amer. Soc. Hort. Sci. 117:951-954.

Zilkah, S., M.E. Osband, and R. McCaffrey. 1981. Effect of inhibitors of plant cell division on mammalian tumor cells in vitro. Cancer Res. 41:1879-1883. 